\title{
TMEM106C is Overexpressed and Modulates Cell Mobility in Metastatic Colon Cancer Cells
}

\section{TMEM106C Metastatik Kolon Kanseri Hücrelerinde Aşırı Eksprese Olmuştur ve Hücre Hareketliliğini Modüle Eder}

\section{Muzaffer Dükel ${ }^{\odot}$}

Molecular Biology and Genetics Department, Faculty of Art and Science, Mehmet Akif Ersoy University, Burdur, Turkey.

\section{ABSTRACT}

olon cancer is the third most commonly diagnosed cancer in worldwide. Colon cancer grows slowly and metastasis has

already occurred after diagnosis. Therefore, new targets are needed in the colon cancer treatment and diagnosis. Transmembrane proteins (TMEM) play a critical role in variety of tumor cells and present different expression profile. TMEM106C is one of TMEM family proteins, but role of this gene in colon cancer development remains unclear. In this study, we aimed to investigate the role of TMEM106C gene in metastatic colon cancer cells. TMEM106C gene expression level was tested by western blot, qRT-PCR and immunofluorescence methods. In order to test the effect of TMEM106C in colon cancer cells, this gene has been knockdown with shRNA technology. In addition, cell invasion, migration and adhesion assays were performed to clarify whether TMEM106C knockdown has effect on colon cancer metastatic characters. For the first time, in this study, we showed that TMEM106C is overexpressed in colon carcinoma cells. Moreover, we demonstrated that cell migration, invasion and adhesion capabilities are reduced in TMEM106C silenced cells. Furthermore, we observed that metastatic cell morphology was changed upon to knockdown of TMEM106C. In conclusion, we showed that TMEM106C gene is important for colon carcinoma cells.

Key Words

Colon cancer, TMEM106C, metastasis

\section{öz}

Kolon kanseri dünya çapında erkekler arasında teşhisi yapılan üçüncü kanser türüdür. Kolon kanseri gelişimi yavaştır ve teşhis konulduğunda metastaz gerçekleşmiştir. Bu nedenle kolon kanserinin teşhis ve tedavisinde yeni hedeflere ihtiyaç duyulmaktadır. Transmembran proteinleri (TMEM) farklı kanserlerin oluşmasında kritik rol oynamaktadır ve ifade seviyeleri çok farklılık göstermektedir. TMEM106C TMEM ailesi proteinlerden birisidir ancak kolon kanseri gelişim sürecindeki görevi bilinmemektedir. Bu çalışmada TMEM106C geninin metastatik kolon kanseri hücrelerindeki görevinin araştırılmaSı amaçlanmıştır. TMEM106C gen ifadesi düzeyi western blot, qRT-PCR ve immünoflöresan yöntemleri ile test edilmiştir. TMEM106C'nin kolon kanseri hücrelerinde ki etkinliğinin test edilmesi için bu gen shRNA teknolojisi yardımıyla inaktive edilmiştir. Ayrıca TMEM106C inaktivasyonunun kolon kanseri metastatik karakterleri üzerine etkisini araştırmak için, hücre invazyon, göç ve adezyon testleri yapılmıştır. Çalışmada ilk defa TMEM106C'nin kolon karsinoma hücrelerinde aşırı ifade edildiği gösterilmiştir. Dahası TMEM106C inaktive edilmiş hücrelerde hücre göçü, invazyon ve adezyon yeteneklerinin azaldığı gösterilmiştir. Ayrıca TMEM106C gen inaktivasyonunun, metastatik hücre morfolojisini değiştirdiği gözlenmiştir. Sonuç olarak bu çalışma kapsamında TMEM106C geninin kolon karsinoma hücrelerindeki etkinliği gösterilmiştir.

\section{Anahtar Kelimeler}

Kolon kanseri, TMEM106C, metastaz.

Article History: Received: Mar 6, 2021; Revised: Jun 1, 2021; Accepted: Jun 25, 2021; Available Online: Jun 25, 2021. DOI: https://doi.org/10.15671/hjbc.892060

Correspondence to: M. Dukel, Molecular Biology and Genetics Department, Mehmet Akif Ersoy University, Burdur, Turkey. E-Mail: mdukel@mehmetakif.edu.tr/muzafferdukel@gmail.com 


\section{INTRODUCTION}

n worldwide, over a million new colon cancer cases are diagnosed every year and more than half of them die [1]. One of every 4 colon cancer diagnoses has already metastasised that presents low survival [2]. Although the most important reason of cancer caused death is metastasis, biology of metastases has not been totally understood. As the metastasis cascade is responsible for $90 \%$ of cancer caused deaths in humans, cancer metastasis is one of the most important points that should be emphasized and investigated $[3,4]$. During metastasis, cancer cells acquire the ability to spread from the primary tumor to secondary tissues or organs via altered cellular processes such as inhibition of apoptosis, uncontrolled division, loss of cell-cell or cell- extracellular matrix (ECM) adhesion, migration ability, and loss of ECM connectivity $[3,5,6]$. Alterations in the adhesive properties of tumor cells rely on both up-regulation and down regulation of cell adhesion molecules (CAM) that facilitates metastasis [7, 8]. Transmembrane proteins (TMEMs) are a large family of proteins that are located both cell membrane and various organel membranes, and perform different functions in different cell types [9]. TMEM proteins present different expression profiles in cancer as both tumor suppressors and oncogenes. In addition, several studies indicated that TMEMs play vital roles in metastasis formation by regulation of local invasion, migration and intravasation/extravasation $[9,10]$. Moreover numerous studies demonstrated that TMEM proteins involved carcinogenesis in many cancer types including colon [11], esophageal [12], non-small cell lung carcinoma [13], breast and liver [14], and ovarian [15], hepatocellular carcinoma (HCC) [16]. Furthermore, some TMEM proteins such as TMEM25, TMEM158 and TMEM 140 are involved into regulating adhesion in tumor growth [9].

TMEM106C is a TMEM family member, that has two paralogs (TMEM 106A and B), and has not been intensively investigated for carcinogenesis. Functions of TMEM106C are not fully understood while TMEM106A and TMEM106B proteins were tested for their functions in some cellular processes including lysosomal activities and apoptosis [17]. In addition, earlier studies demonstrated that TMEM106A is downregulated in renal [18] and gastric [17] cancer cells and overexpression of TMEM106A results in alterations in characteristics of metastasis. Others showed that TMEM106B may also involve the development of genetic disease [19, 20]. Although some recent works indicated that elevated TMEM106C is crucial for carcinogenesis of hepatocellular carcinoma (HCC), effects of TMEM106C on cancer cell metastatic characteristics are unknown $[16,21]$.
In this study, we aim to investigate expression of TMEM106C in several colon cancer cells. Thereby, we tested whether absence of TMEM106C affects characteristic of metastasis in colon carcinoma cells such as cell adhesion, invasion and migration. We found out that TMEM106C is overexpressed in colon carcinoma cells and knock down of this gene modulates cell adhesion, invasion and migration in Colo 201 and Colo 205 cells. Overall, our data show that TMEM106C is important for colon carcinogenesis and might be a new prognostic biomarker.

\section{MATERIALS and METHODS}

\section{Cell lines and culture}

The normal colon cell line, CCD-18Co and colon cancer cell lines SW480, DLD-1, SW620, Caco-2, HCT-116, Colo 201 and Colo 205 were obtained from ATCC and passaged for less than 6 months after resuscitation. All cell lines were cultured under standard mammalian tissue culture conditions and sterile techniques. For each cell line, we used the growth media recommended by ATCC. Colo 201 and Colo 205 cells were cultured within RPMI-1640 medium (Thermo Fisher Sci.) containing L-glutamine ( $4 \mathrm{mM})$, fetal bovine serum (10\%), penicillin $(100 \mathrm{U} / \mathrm{ml})$ and streptomycin (100 $\mu \mathrm{g} / \mathrm{ml})$.

\section{Immunoblot analysis}

Immunoblotting was performed as described previously [22]. Briefly, the cells were lysed in cold RIPA buffer (Cat. No. ab156034: Abcam) supplemented with a protease inhibitor mixture. After centrifugation at $13,000 \mathrm{rpm}, 40 \mathrm{O}$ for 30 min, supernatant was transferred to new tubes and protein concentration was quantified using a BCA protein assay kit (CST, Prod\#7780). $40 \mu \mathrm{g}$ protein for each sample was loaded onto SDS-PAGE gels and transferred to nitrocellulose membranes e (Cat. No. 88018; Thermo Fisher Scientific). The membranes were probed with anti-TMEM106C (NBP1-59829; 1:2000 dilution; Novus Biologicals, Littleton, CO), and anti- $\beta$-actin (sc-47778; 1:5000 dilutions; Santa Cruz Biotechnology) as loading control, and was then incubated with the horseradish peroxidase (HRP)-conjugated secondary antibody (1:2000 dilution cell signalling). Immunobloting signals were visualized via chemiluminescent substrates (Thermo Scientific) and imaged with a LI-COR Imaging System quantitated with Image J software. 


\section{Gene Knockdown}

For TMEM106C shRNA knockdown, lentivirus encoding shRNA or nonspecific shRNA insert sequence were obtained from Santa Cruz Biotechnology (Cat no: sc-95861SH; shTMEM106C, shControl; sc-108060). To knock down TMEM106C, we followed manufacturers protocol for shRNA. Lentivirus encoding shRNA or control vector were packaged in HEK-293FT cells with psPAX2 and pMD2.G plasmids for virus production. Colo 201 and Colo 205cells were seeded into six well plates at $2 \times 10^{5}$ and were then applied with virus. Next, cells were selected for $\sim 2-3$ weeks with $2 \mu \mathrm{g} / \mathrm{ml}$ Puromycin.

\section{mRNA quantification with qRT-PCR}

Total RNA was isolated using RNA purification kit (RNeasy Plus Mini Kit, Qiagen, Germany) according to the manufacturers' instructions. After RNA quantification, 500 ng RNA was then used for cDNA synthesis with High-Capacity RNA to cDNA kit (Cat No: 4388950, ThermoFisher). For each qRT-PCR reaction $10 \mu \mathrm{L}$ reaction was assembled with 1

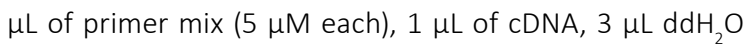
and $5 \mu \mathrm{L}$ of SYBR Green master mix (Applied Biosystems, Norwalk, CT). qRT-PCR reactions were carried out in Applied Biosystems 7900 HT Fast. Fold changes in transcript abundance were calculated by the $2^{-\Delta \Delta c t}$ method [23] using GAPDH as the internal standard. Table 1 shows primer list for qRT-PCR experiments.

\section{Cell Adhesion Assay}

To test the effect of TMEM106C knocdown on cell-ECM or cell-cell interaction of colon carcinoma cells, we performed cell adhesion assay with the CytoSelectTM 48well cell adhesion assay (Cell Biolabs, Inc. CBA-070, San Diego, CA, USA). Following manufacturers protocol for this assay, briefly, cells $\left(1 \times 10^{6}\right)$ were seeded for $48 \mathrm{~h}$ as control cells. Non-adherent cells were washed and the adherent cell then were stained with Crystal blue dye solution for 20 min. Finally, absorbance of stained cells was measured at optical density $\left(O D_{\max }=540\right)$. All the experiments were performed in triplicate.

\section{Migration Assay}

In vitro cell migration level of Colo 201 and Colo 205 cells upon TMEM106C silencing was evaluated by Radius $^{\text {TM }}$ 24-well Cell Migration Assay kit (Cell Biolabs, San Diego, CA) according to the manufacturer's protocol. Before plating cells, all plates were incubated at room temperature for $20 \mathrm{~min}$ and each well then was washed with wash solution. Both TMEM106C knockdown and control cells $\left(1 \times 10^{5}\right)$ were seeded and incubated for $24 \mathrm{~h}$ for cell attachment. Migrated cell was monitored under an inverted light microscope at 60x magnification (Olympus, Japan) and was analyzed using Image J software.

\section{Invasion assays}

A cell invasion assay was conducted using a CytoSelectTM 48-well Cell Invasion assay kit (Cell Biolabs, San Diego, CA). Briefly, TMEM106C knockdown Colo 201 and Colo 205 cells were harvested and $2 \times 10{ }^{5}$ cells were placed into the chamber. Cells in the upper chamber of the assay plate were covered with a layer of collagen and were then incubated for $48 \mathrm{~h}$ at 37ㅇ $\mathrm{C}$ in $5 \%$ CO2 atmosphere. Cells were stained with Cell Stain Solution and then invasive cells were measured at the OD $560 \mathrm{~nm}$ in plate reader.

\section{Statistical analysis}

Student's-test (two-tailed) was performed to evaluate the significant differences between groups. ANOVA (Dunnett's post hoc test) was applied to compare significant difference among multiple groups. All statistical values were presented as the means \pm standard deviation (SD). P values less than 0.05 were regarded as significant

Table 1. TMEM106C and GAPDH primes used in this study.

\begin{tabular}{clc}
\hline Gene & Forward & Reverse \\
\hline TMEM106C & GGTTTCTCCTGCTTCACTGC & CAGGATGGACAGGAGGACAT \\
\hline GAPDH & CTCCCACCTTTCTCATCCAA & TGGACTGTGGTCTGCAAAAG \\
\hline
\end{tabular}


A)

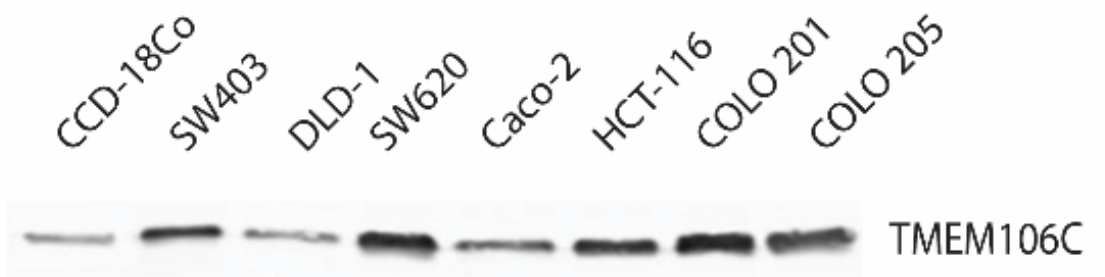

B)

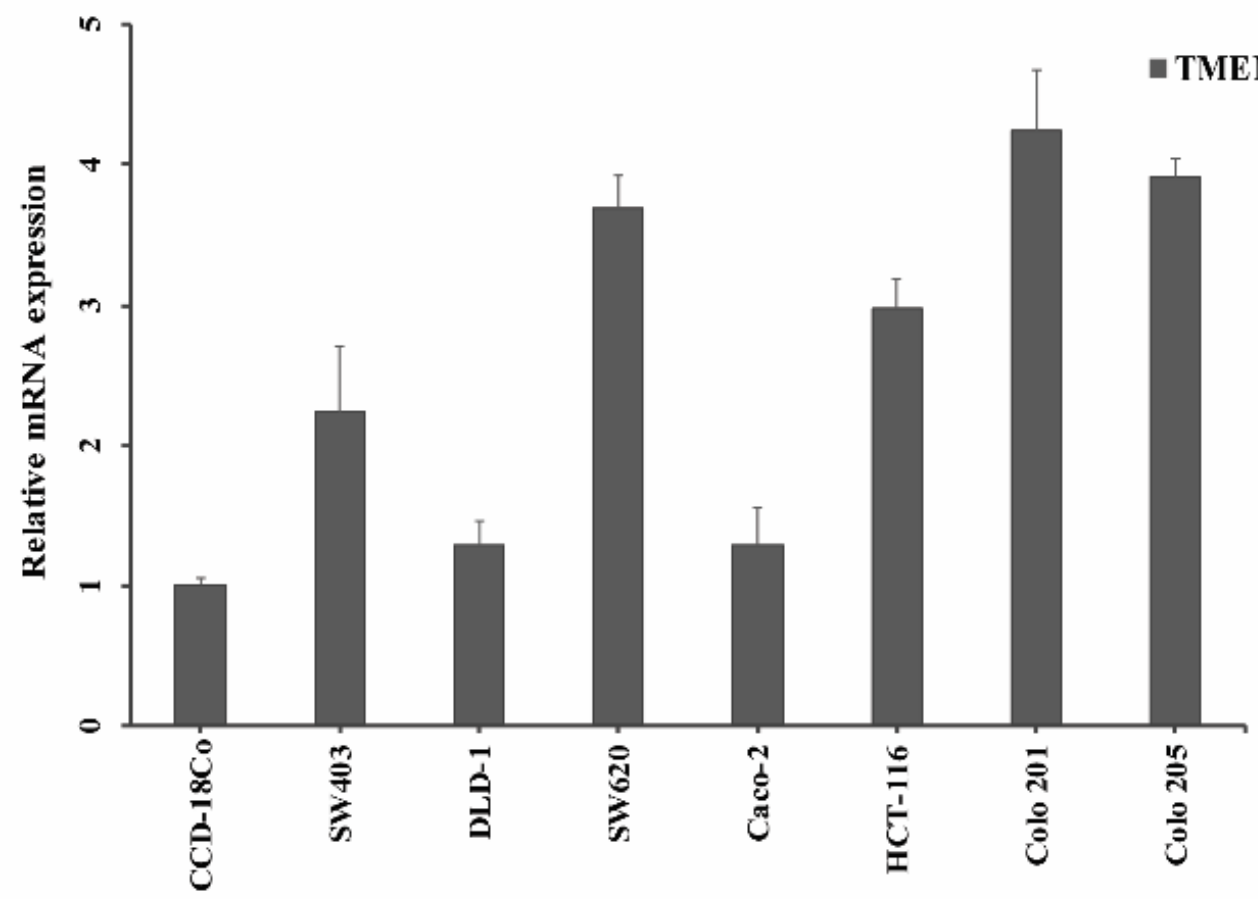

Figure 1. Protein and mRNA levels of TMEM106C in colon cancer cell lines. A) Protein expression levels of TMEM106C in human colon cancer cell lines and normal colon cell line were determined by immunoblotting analysis. Cells were harvested and lysates were immunoblotted with TMEM106C and $\beta$-Actin as a loading control. B) Total RNA was isolated from cell lines and then TMEM106C transcript abundance was measured by qRT-PCR. GAPDH was used as a housekeeping gene.

\section{RESULTS}

\section{TMEM106C is upregulated in colon carcinoma cells lines}

To assess the abundance of TMEM106C protein and mRNA levels in 7 colon cancer cell lines and 1 normal colon cell line western blotting was used. Western blot data showed that TMEM106C is overexpressed in metastatic colon cell lines SW620, HCT116, Colo 201 and Colo 205. On the other hand, adenocarcinoma cell lines Caco-2 and DLD-1 presented lower level TMEM106C proteins as well as CCD-18Co cell line (Fig 1A). Consistent with immunoblotting data, qRT-PCR results dem- onstrated that the expression levels of TMEM106C was remarkably higher in colon carcinoma cell lines, such as Colo 201 and Colo 205, compared to normal colon cells (Fig 1B).

\section{ShRNA knockdown of TMEM106C reduces colon carcinoma cell migration and invasion capacity}

The recent work of Luo and colleagues demonstrated that, knockdown of TMEM106C in HCC cells altered celIular behavior [16]. Others have also recently observed that TMEM106C is associated with altered malignant characteristics [21]. To extend these findings for colon cancer cells, we investigated the effect of TMEM106C 
on the metastatic capacity of Colo 201 and Colo 205 cells. Firstly, we used shRNA technology to knockdown TMEM106C for indicated cell lines. Immunoblotting bands indicated that there was a multifold reduction in TMEM106C for shTMEM106C compared with control shRNA vector (Fig 2A). To determine whether TMEM106C affects invasive and migratory abilities in colon carcinoma cells, we used commercially available kit as mentioned at materials and methods section. After 48 hours wounding monolayer cultures, migration of indicated cell lines was observed under microscope and pictures were taken in the 0 and 48 hours. We found out that each TMEM106C knockdown line has decreased cell migration compared with control groups. Cells were counted 48 hours of incubation compared with time 0 and data showed that significant reduced colon cancer cell migration ( $<<0.01$ ) (Fig 2B). Invasion assays were conducted using a modified Boyden chamber. We also observed statistically significant reduction in invasive activity of TMEM106C knockdown cells (Fig 2C). Collectively, our data indicate that TMEM106C is important for metastatic cell motility for both Colo 201 and Colo 205 metastatic colon tumor cell lines.

A)

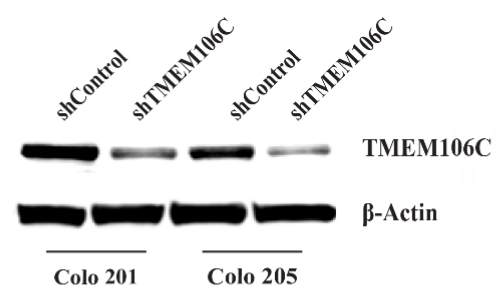

shControl shTMEM106C

$\mathbf{0 ~ h}$

B)
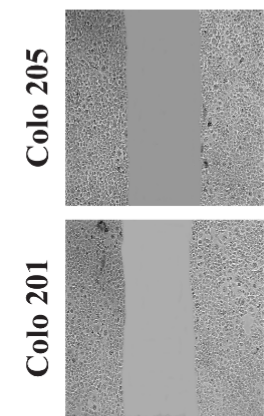

C)

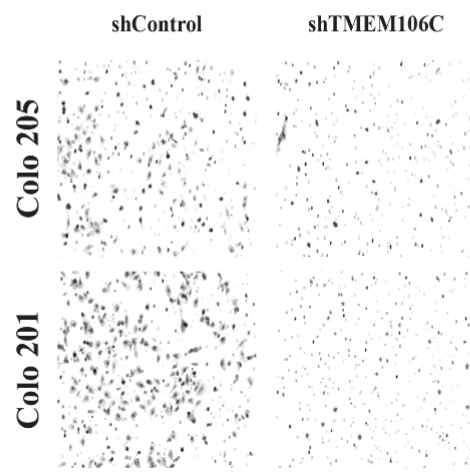

$\mathbf{0 h}$
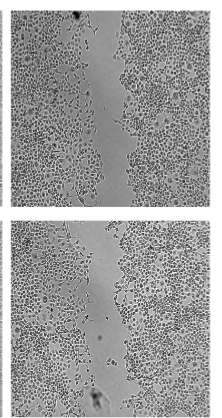

$48 \mathrm{~h}$
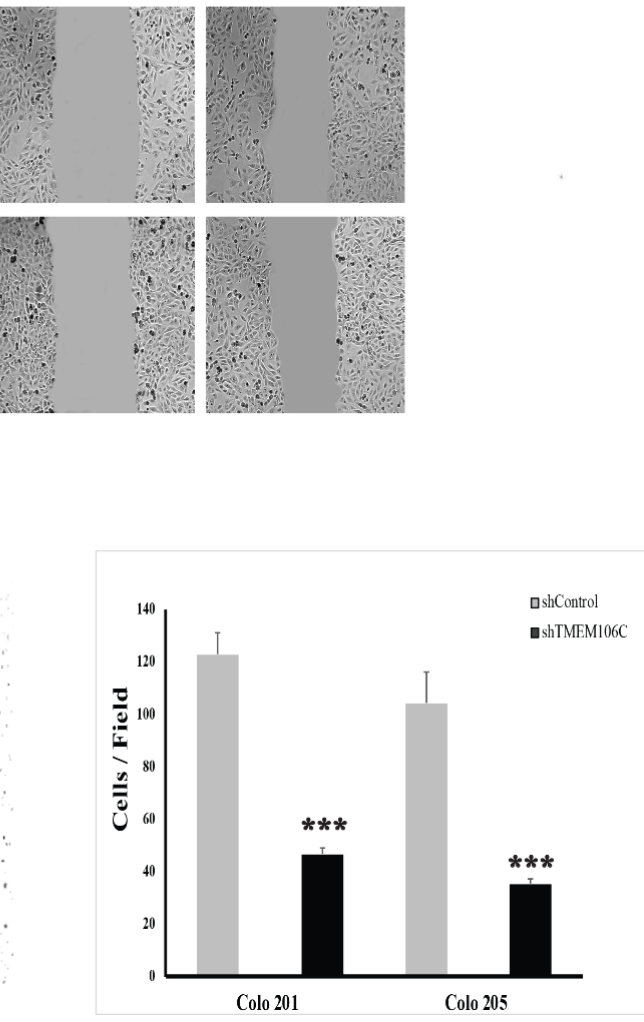

Figure 2. TMEM106C knockdown inhibited colon carcinoma cells migration, and invasion TMEM106C knockdown in colon carcinoma cell lines reduces cell motility and invasiveness A) TMEM106C knockdown Colo 201 and Colo 205 cells were immunoblotted with TMEM106C and $\beta$-Actin as a loading control. B) and C) Colon cell migration and invasion were measured by transwell migration assays, and invasion assays, respectively. Pictures show relative migration and invasion rates of control and TMEM106C knockdown lines. 
A)

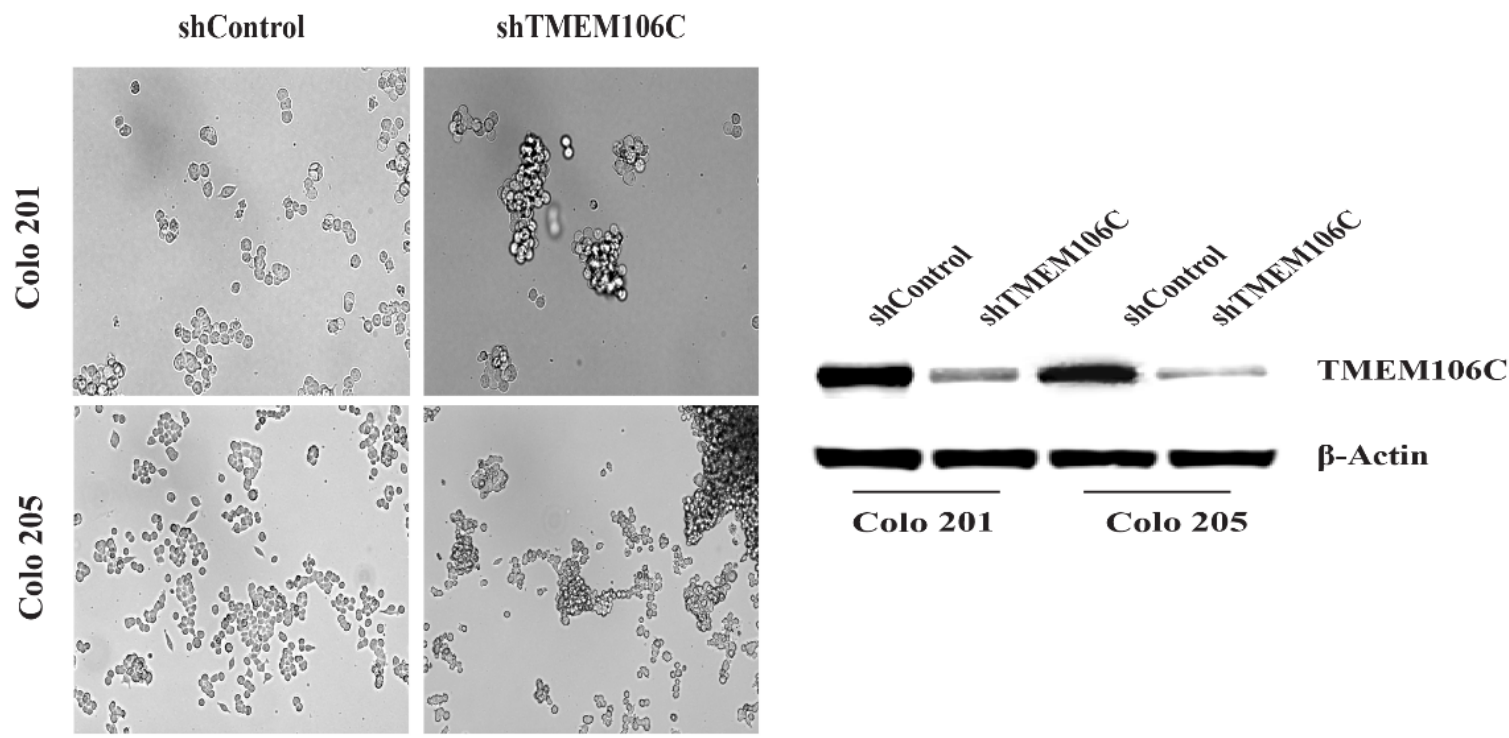

B)

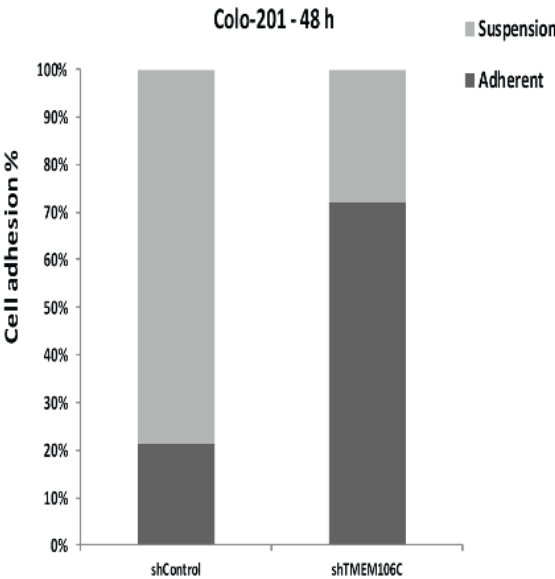

Suspension

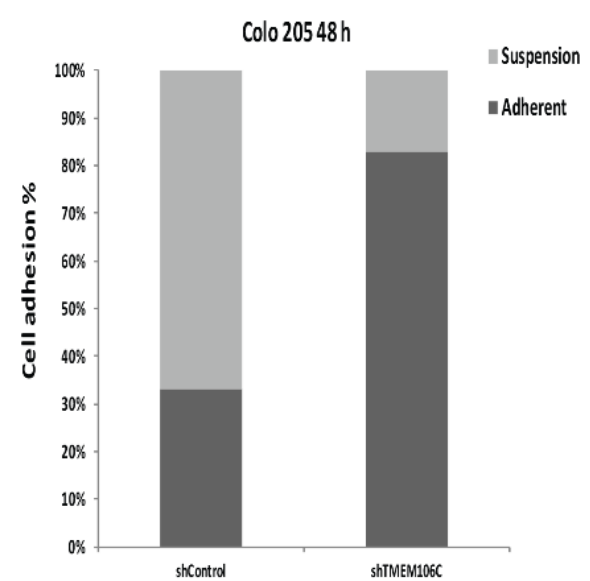

Figure 3. TMEM106C knockdown in colon carcinoma lines alters cell morphology and increases cell adhesion. A) Representative figures shows changed cell morphology and adhesive cells. Immunobloting bands confirm knock down of TMEM106 C cell in both Colo 201 and Colo 205 cell lines. B) Charts indicate relative adhesion rates of control and TMEM106C knockdown lines.

\section{Decreased TMEM106C level suppresses and adhesion of colon carcinoma cells}

Next, we investigated whether reduced TMEM106C expression affect colon cancer cell morphology. Dramatic changes in morphology of Colo 201 and Colo 205 cells following TMEM106C silencing was observed compared to control cells (Fig 3A). Hence, we tested cell adhesion in TMEM106C knockdown cell lines. As detailed in the Materials and methods section, the adhesion assay was completed four times with Cytoselect Adhesion assay kit. We observed that TMEM106C silenced Colo 201 and Colo 205 cells were more adherent to control groups. Both cell lines demonstrated more than 2-fold increased adhesive cells (Fig 3B). These data support that TMEM106C has a functional role in mediating coIon carcinoma cell adhesion. Importantly, we showed for the first time that a TMEM protein family was involved in regulating cell adhesion. 


\section{DISCUSSION}

Colon cancer grows slowly and metastasis has already occurred in many cases after diagnosis. Colon cancer metastasis includes several distinct steps that are tightly regulated [24]. To date, the regulatory mechanisms and signaling pathways underlying colon cancer metastasis remain unclear and new diagnostic markers are needed to be identified. In several studies, TMEM proteins presents oncogenic properties in various cancer types. Qiao et al. showed that TMEM48 expression was overexpressed in lung cancer and evaluated TMEM48 level associated with lung cancer metastasis [13]. Early work indicated that high TMEM45 is important for chemoresistance in breast and liver cancer and this gene can be a biomarker for drug resistance [14]. Others showed that inhibition of TMEM45A altered oncogenic properties of ovarian cancer cells [15]. Xiao and colleagues indicated that TMEM97 is crucial for breast tumor progression and is related to poor survival [25]. In contrast, others reported that TMEM proteins can exert tumor suppressor functions. Zhou and colleagues observed that TMEM7 was genetically silenced and overexpression of TMEM7 suppressed HCC cell lines proliferation [26]. TMEM106C is a TMEM protein family member [9] and little known about role of TMEM106C during carcinogenesis. Few studies have been verified that TMEM106C and its paralogs play important role during carcinogenesis [16-18, 21]. Of note, these investigators points that TMEM proteins are important for tumor progression. Therefore, we evaluated expression of TMEM106C in colon cancer cell lines. Consistently, we found out that TMEM106C is upregulated in colon carcinoma cells both protein and mRNA levels.

Recent reports showed that TMEM106C is overexpressed and plays an important role in the progression of HCC $[16,21]$. On the other hand, TMEM106A acts as a tumor suppressor in both renal and gastric tumors $[17,18]$. We hypothesized that silencing of TMEM106C would affect aggressiveness of colon cancer cells by changing their ability of adhere, invade and migrate. Migration assay demonstrated that a significant decrease in migratory tendency in TMEM106C knockdown Colo 201 and Colo 205 cell lines. In addition, Matrigel-based invasion assay showed that significant reduction in invasive potential in the knockdown cells compared to control groups.
An earlier study showed that TMEM106B is located in lysosome and is important in both lysosomal function and dendrite morphology [27]. Li and colleagues also found out that TMEM59, which another member of TMEM proteins family, mediates neural stem cell morphogenesis [28]. It is well-known that invasive tumor cells acquire loss off cell-cell and cell ECM adhesion. In addition, cancer cell invasion, migration and adhesion are related to each other and are vital for carcinogenesis [29]. In this study, we also observed that inhibition of TMEM106C altered cell morphology of colon carcinoma cells. Further, our cell adhesion results demonstrated that TMEM106C modulated adhesive characteristic of both Colo 201 and Colo 205 cells line, which grows in suspension. Taken together, these data indicated that TMEM106C can be important for colon cancer metastasis cascade.

\section{CONCLUSIONS}

In conclusion, this study has showed that TMEM106C may promote invasion and metastasis in colon cancer and it might be a new diagnostic and therapeutic target in colon cancer. However, we did not fully demonstrate how TMEM106C could effect colon cancer carcinogenesis signaling in detailed. Further study should be performed to address interaction between TMEM106C and colon cancer carcinogenesis signaling in detail.

\section{Acknowledgments}

We would like to thank Prof. Dr. Hulya Ayar Kayalı (Dokuz Eylul University) for the kind gifts of colon cancer cells. There is not conflicts of interest.

\section{References}

1. F. Bray, J. Ferlay, I. Soerjomataram, R.L. Siegel, L.A. Torre, A. Jemal, Global cancer statistics 2018: GLOBOCAN estimates of incidence and mortality worldwide for 36 cancers in 185 countries, CA. Cancer J. Clin., 68 (2018) 394-424.

2. P. Rawla, T. Sunkara, A. Barsouk, Epidemiology of colorectal cancer: incidence, mortality, survival, and risk factors, Prz. Gastroenterol., 14 (2019) 89-103.

3. T.N. Seyfried, L.C. Huysentruyt, On the origin of cancer metastasis, Crit. Rev. Oncog., 18 (2013) 43-73.

4. H. Dillekås, M.S. Rogers, O. Straume, Are $90 \%$ of deaths from cancer caused by metastases?, Cancer Med., 8 (2019) 55745576.

5. J.A. Joyce, J.W. Pollard, Microenvironmental regulation of metastasis, Nat. Rev. Cancer, 9, (2009) 239-252. 
6. S. Sakamoto, N. Kyprianou, Targeting anoikis resistance in prostate cancer metastasis. Mol. Aspects Med., 31 (2010) 205-214.

7. G. Bendas, L. Borsig, Cancer cell adhesion and metastasis: selectins, integrins, and the inhibitory potential of heparins, Int. J. Cell Biol., 2012 (2012) 676731.

8. U. Cavallaro, G. Christofori, Cell adhesion in tumor invasion and metastasis: loss of the glue is not enough, Biochim. Biophys. Acta, 1552, (2001), 39-45.

9. K. Schmit, C. Michiels, TMEM Proteins in Cancer: A Review, Frot. Pharmacol., 9 (2018) 1345.

10. S. Marx, T. Dal Maso, J.-W. Chen, M. Bury, J. Wouters, C. Michiels, B. Le Calvé, Transmembrane (TMEM) protein family members: Poorly characterized even if essential for the metastatic process, Semin. Cancer Biol., 60 (2020) 96106.

11. S. Hrašovec, N. Hauptman, D. Glavač, F. Jelenc, M. RavnikGlavač, TMEM25 is a candidate biomarker methylated and down-regulated in colorectal cancer, Dis. Markers., 34 (2013) 93-104.

12. Y. Wang, Y. Zhang, J.G. Herman, E. Linghu, M. Guo, Epigenetic silencing of TMEM176A promotes esophageal squamous cell cancer development, Oncotarget., 8 (2017) 70035-70048.

13. W. Qiao, Y. Han, W. Jin, M. Tian, P. Chen, J. Min, H. Hu, B. $\mathrm{Xu}, \mathrm{W}$. Zhu, L. Xiong, Q. Lin, Overexpression and biological function of TMEM48 in non-small cell lung carcinoma, Tumour Biol., 37 (2016) 2575-2586.

14. L. Flamant, E. Roegiers, M. Pierre, A. Hayez, C. Sterpin, O. De Backer, T. Arnould, Y. Poumay, C. Michiels, TMEM45A is essential for hypoxia-induced chemoresistance in breast and liver cancer cells. BMC Cancer, 12 (2012) 391.

15. J. Guo, L. Chen, N. Luo, W. Yang, X. Qu, Z. Cheng, Inhibition of TMEM45A suppresses proliferation, induces cell cycle arrest and reduces cell invasion in human ovarian cancer cells, Oncol. Rep., 33 (2015) 3124-3130.

16. X. Luo, G. Han, R. Lu, S. Guan, Y. Wang, L. Ju, L. Chen, J. Shao, Z. Bian, Transmembrane protein $106 \mathrm{C}$ promotes the development of hepatocellular carcinoma, J. Cell. Biochem., 121 (2020) 4484-4495

17. D. $\mathrm{Xu}, \mathrm{L} . \mathrm{Qu}$, J. Hu, G. Li, P. Lv, D. Ma, M. Guo, Y. Chen, Transmembrane protein 106A is silenced by promoter region hypermethylation and suppresses gastric cancer growth by inducing apoptosis, J. Cell. Mol. Med., 18 (2014) 1655-1666.

18. C. Wu, J. Xu, H. Wang, J. Zhang, J. Zhong, X. Zou, Y. Chen, G. Yang, Y. Zhong, D. Lai, X. Li, A. Tang, TMEM106a is a novel tumor suppressor in human renal cancer, Kidney Blood Press. Res., 42 (2017), 853-864.
19. R. Vass, E. Ashbridge, F. Geser, W.T. Hu, M. Grossman, D. Clay-Falcone, L. Elman, L. McCluskey, V.M.Y. Lee, V.M. Van Deerlin, J.Q. Trojanowski, A.S. Chen-Plotkin, Risk genotypes at TMEM106B are associated with cognitive impairment in amyotrophic lateral sclerosis, Acta Neuropathol., 121 (2011) 373-380.

20. N.J. Rutherford, M.M. Carrasquillo, M. Li, G. Bisceglio, J. Menke, K.A. Josephs, J.E. Parisi, R.C. Petersen, N.R. GraffRadford, S.G. Younkin, D.W. Dickson, R. Rademakers, TMEM106B risk variant is implicated in the pathologic presentation of Alzheimer disease, Neurology, 79 (2012) 717-718.

21. J. Duan, Y. Qian, X. Fu, M. Chen, K. Liu, H. Liu, J. Yang, C. Liu, Y. Chang, TMEM106C contributes to the malignant characteristics and poor prognosis of hepatocellular carcinoma, Aging (Albany. NY). 13, (2021) 1-22.

22. M. Dükel, W.S. Streitfeld, T.C.C. Tang, L. R.F. Backman, L. Ai, W.S. May, K.D. Brown, The breast cancer tumor suppressor TRIM29 is expressed in an ATM-dependent manner in response to hypoxia, J. Biol. Chem., 291 (2016) 21541-21552.

23. K.J. Livak, T.D. Schmittgen, Analysis of relative gene expression data using real-time quantitative PCR and the $2^{\wedge}(-\Delta \Delta C T)$ method, Methods 25 (2001) 402-408.

24. C.A.J. Portera, R.S. Berman, L.M. Ellis, Molecular determinants of colon cancer metastasis, Surg. Oncol., 7 (1998) 183-195.

25. M. Xiao, H. Li, S. Yang, Y. Huang, S. Jia, H. Wang, J. Wang, Z. $\mathrm{Li}$, Expression of MAC30 protein is related to survival and clinicopathological variables in breast cancer, J. Surg. Oncol., 107 (2013) 456-462.

26. X. Zhou, N.C. Popescu, G. Klein, S. Imreh, The interferonalpha responsive gene TMEM7 suppresses cell proliferation and is downregulated in human hepatocellular carcinoma, Cancer Genet. Cytogenet, 177 (2007) 6-15.

27. B.M. Schwenk, C.M. Lang, S. Hogl, S. Tahirovic, D. Orozco, K. Rentzsch, S.F. Lichtenthaler, C.C. Hoogenraad, A. Capell, C. Haass, D. Edbauer, The FTLD risk factor TMEM106B and MAP6 control dendritic trafficking of lysosomes, EMBO J., 33 (2014) 450-467.

28. X. Li, R. Feng, C. Huang, H. Wang, J. Wang, Z. Zhang, H. Yan, T. Wen, MicroRNA-351 regulates TMEM 59 (DCF1) expression and mediates neural stem cell morphogenesis, RNA Biol., 9 (2012) 292-301.

29. J. Behrens, The role of cell adhesion molecules in cancer invasion and metastasis, Breast Cancer Res. Treat., 24 (1993) 175-184. 